\title{
ArcheoSciences
}

Revue d'archéométrie

33 (suppl.) | 2009

Mémoire du sol, espace des hommes

\section{Geophysical prospection and aerial photography in La Laguna, Tlaxcala, Mexico}

Luis Barba, Jorge Blancas, Agustin Ortiz and David Carballo

\section{OpenEdition}

1 Journals

\section{Electronic version}

URL: https://journals.openedition.org/archeosciences/1194

DOI: 10.4000/archeosciences. 1194

ISBN: 978-2-7535-1599-4

ISSN: 2104-3728

Publisher

Presses universitaires de Rennes

\section{Printed version}

Date of publication: 30 October 2009

Number of pages: $17-20$

ISBN: 978-2-7535-0943-6

ISSN: 1960-1360

\section{Electronic reference}

Luis Barba, Jorge Blancas, Agustin Ortiz and David Carballo, "Geophysical prospection and aerial photography in La Laguna, Tlaxcala, Mexico", ArcheoSciences [Online], 33 (suppl.) | 2009, Online since 30 October 2011, connection on 21 September 2021. URL: http://journals.openedition.org/ archeosciences/1194; DOI: https://doi.org/10.4000/archeosciences.1194 


\title{
Geophysical prospection and aerial photography in La Laguna, Tlaxcala, Mexico
}

\author{
Luis Barba*, Jorge Blancas*, Agustin Ortiz* and David Carballo **
}

Key words: Prospection, Aerial photography, GPR, Magnetic gradient, Electrical resistivity.

\section{INTRODUCTION}

The paper presents the results of a remote-sensing program at the La Laguna archaeological site, a Late Formative period (c. $600 \mathrm{BC}-\mathrm{AD} 100$ ) regional center located in northern Tlaxcala $\left(19^{\circ} 30^{\prime} 35^{\prime \prime} \mathrm{N} / 98^{\circ} 00^{\prime} 20^{\prime \prime} \mathrm{W}\right)$. The site was the largest community in the region during this period, when adjacent areas of central Mexico witnessed an initial phase of urbanization and state formation (Carballo and Pluckhahn, 2007; Merino Carrión, 1989; Snow, 1966). As such, La Laguna provides a critical, more rural perspective on these macroregional-scale developments surrounding the community to the west, south, and east.

Methods of prospection included ground-penetrating radar (GPR), magnetic gradient, electrical resistivity, and aerial photography in order to document architectural and cultural features at the site center. Except for the largest structures, most of the architecture is covered up as a result of the site's location in a saddle between three surrounding hills (Fig. 1). As previous excavations at La Laguna had documented the use of volcanic stone as building material, magnetic gradient was chosen as the primary method of analysis following success in the mapping of the architecture of the La Loma site in Zacapu, Michoacan (Hesse et al., 1997; Link and Barba, 2001).

\section{Aerial Photography}

Aerial photos were acquired using a captive, helium-filled balloon with remote-operated camera. Images taken in a 50-150 m elevation range were combined in a photo-mosaic in an effort to seek out subtle changes in elevation and vegetation that could correspond to buried structures (Fig. 2). The high resolution mosaic covers approximately 4.5 ha of the center of the site, encompassing its central plaza, ballcourt, and largest platform mounds.

\section{Magnetic Gradient}

The surface of the site center was gridded with $20 \times 20$ $\mathrm{m}$ squares that served as references for running parallel transects every $1 \mathrm{~m}$. A total of 52 squares was registered with a Geoscan FM36, covering an area of $20,800 \mathrm{~m}^{2}$. The recorded data were processed in order to correct errors and minimize magnetic noise using several techniques available in Geoplot software; these included interpolation, despike, and zero-mean grid. After processing, data were configured in Transform and Surfer as pseudo-color relief maps to highlight anomalies such as magnetic dipoles along the limits of structures, surface materials, and buried walls.

\footnotetext{
* Instituto de Investigaciones Antropológicas, UNAM, Ciudad Universitaria, 04510, Mexico City, México. (barba@unam.mx), (jorgeblancasvaz@ gmail.com),(ortiz@unam.mx)

** Cotsen Institute of Archaeology, University of California, Los Angeles. (david.m.carballo@gmail.com)
} 


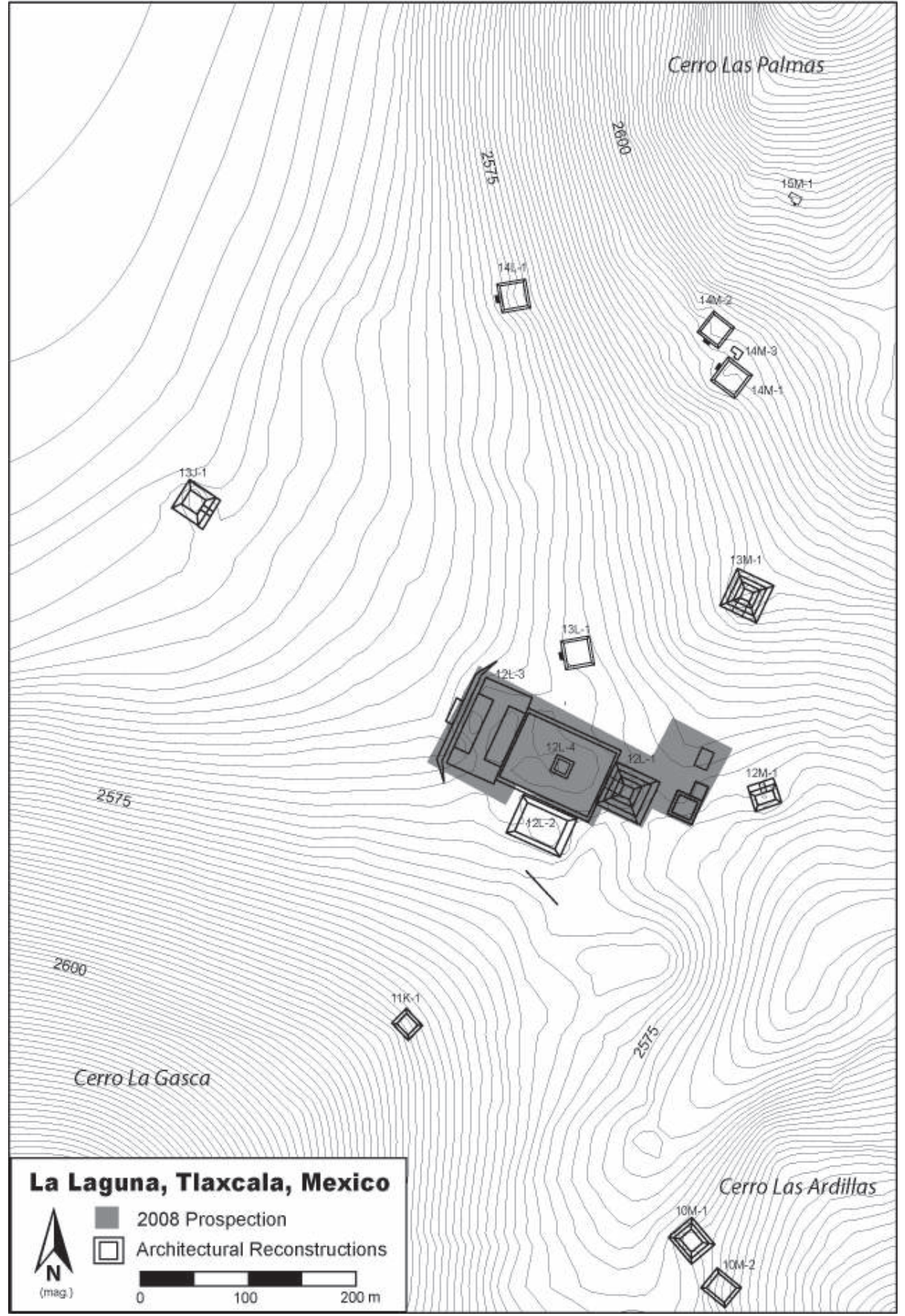

Figure 1: La Laguna with architectural reconstructions and area of prospection shaded in gray.
The map generated using the magnetic gradient revealed the location of a hypothesized ballcourt, in which parallel surface elevations are articulated with subsurface construction enclosing the structure in the form of a typical I-shaped Mesoamerican ballcourt. A visible surface rise in the center of the plaza corresponds with a subsurface concentration of stone that likely forms a central altar. To the east is a probable temple platform (Structure 12L-1), and the strong signal to the north of the plaza, $100 \mathrm{~m}$ long and $10 \mathrm{~m}$ wide, likely indicates a stepped wall, suggesting that the plaza is sunken relative to its surroundings.

Other unexpected discoveries were the stone features to the east of Structure 12L-1, not visible on the surface. They may correspond to low platforms of a residential or public function. A series of magnetic dipoles associated with the structures may correspond to burnt areas, such as the char- 
Figure 2: Digital terrain model for the central portion of La Laguna.

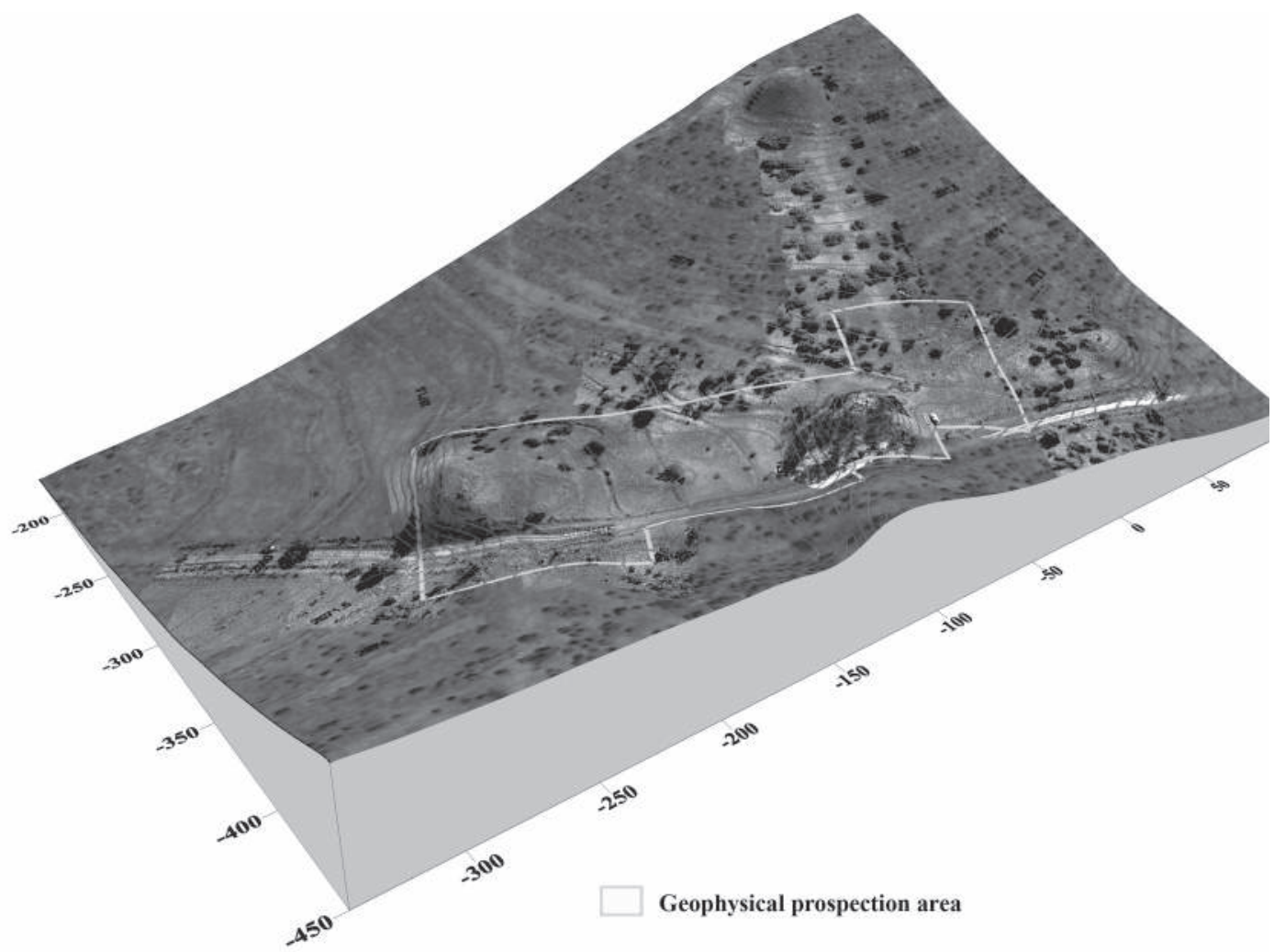

red circular features (Snow, 1966) documented in the area in the 1960s. Possibilities for these include maguey roasting ovens or ceramic kilns, but excavation is required to determine this. Anomalies to the northeast of the magneticgradient map are in an area of previous excavations which uncovered small walls, a burial, and pit-features. They likely are indicative of features of a similar kind.

The magnetic-gradient study was extremely productive in identifying the form and orientation of several architectural features visible from the surface and in documenting others that are not, together with their corresponding cultural deposits. The I-shaped ballcourt is currently also the earliest registered for the state of Tlaxcala.

\section{Ground Penetrating Radar and ELECTRICAL Resistivity}

GPR and electrical resistivity were used to complement the magnetic-gradient study. A total of 54 transects by GPR covered 2175 m using a GSSI SIR System 2 with $400 \mathrm{MHz}$ antenna. An additional two transects, measuring 60 and $100 \mathrm{~m}$, were registered by electric gradient using a Geoscan RM15 - focused on the area connecting the ballcourt to the central altar.
An excellent vertical correspondence was also registered between the results of the GPR and the electrical resistivity at the northern articulation between the ballcourt and central plaza, demonstrating the rise from the playing ground to the eastern bench and the drop to plaza level (Fig. 3).

\section{References}

Carballo, D. and Pluckhahn, T., 2007. Transportation Corridors and Political Evolution in Highland Mesoamerica: Settlement Analyses Incorporating GIS for Northern Tlaxcala, Mexico. Journal of Anthropological Archaeology, 26(4): 607-629.

CARrión, M. and LeONor, B., 1989. La Cultura Tlaxco. Instituto Nacional de Antropología e Historia, México, D.F., Colección Científica 174.

Hesse, A., Barba, L., LinK, K. and Ortiz, A., 1997. A Magnetic and Electrical Study of Archaeological Structures at Loma Alta, Michoacan, Mexico. Archaeological Prospection, 4: 53-67.

LINK, K. and BARBA, L., 2001. Combined visualization of electrical and magnetic surveys. Prospezioni Archaeologiche "Filtering, Optimization and Modelling of Geophysical Data in Archaeological Prospecting”. Fondazione Lerici. Roma, Italia. 103-112.

SNow, D., 1966. A Seriation of Archaeological Collections from the Rio Zahuapan Drainage, Tlaxcala, Mexico. University Microfilms, 66-12, 984, Ann Arbor, Michigan. 


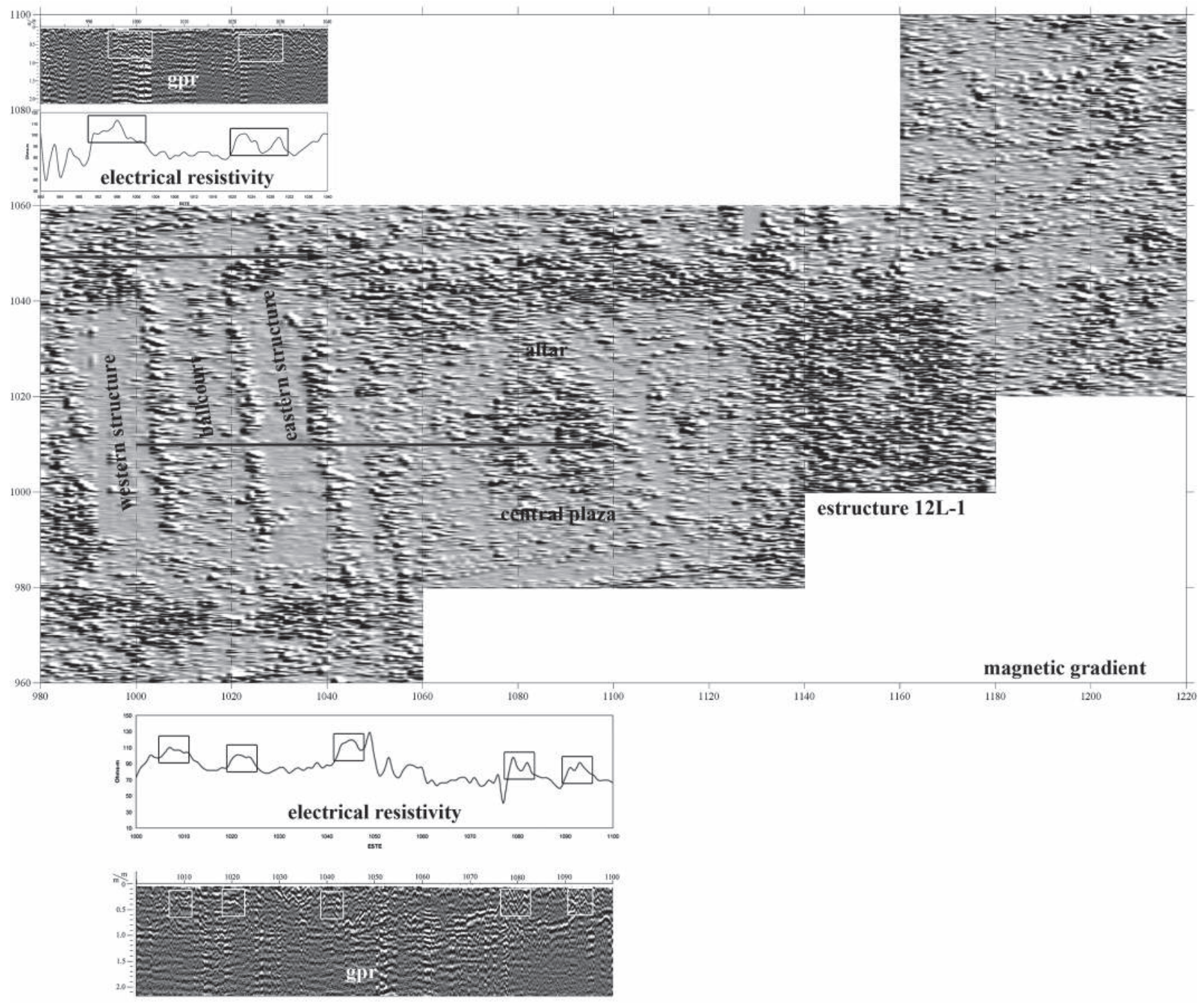

Figure 3: Comparison between the magnetic gradient, electrical resistivity, and GPR at the northern endzone of the ballcourt, extending down to the level of the central plaza. 